\title{
A Study on Hematological Manifestations in Tuberculosis
}

\author{
Dr. S. Siva Kumar ${ }^{1}$ M.D., Dr. N. Kirubanand ${ }^{2}$ M.D., \\ ${ }^{I}$ Associate Professor, Department Of General Medicine, Government Thiruvannamalai Medical College And \\ Hospital \\ ${ }^{2}$ Assistant Professor, Department Of General Medicine, Government Thiruvannamalai Medical College And \\ Hospital
}

\begin{abstract}
Introduction: To study about the hematological manifestations in Tuberculosis to prevent morbidity and mortality due to co morbid conditions like Anemia with cardiac failure, Pancytopenia, etc.,

Aims And Objectives: The study is done to evaluate the presence, extent and severity of hematological manifestations in Pulmonary and Extra pulmonary Tuberculosis.

Materials And Methods: The study was conducted among 100 patients in Government Thiruvannamalai medical college and hospital from June 2014 to April 2015. A detailed history was elicited, clinical examination and all required investigations were done for all cases.

Statistical Analysis: The data was analysed with the help of softwares such as SPSS 14, Microsoft Excel 2013, Medcalc And Genstat Version 9.0

Summary: The commonest hematological findings were raised ESR 84\%, followed by anemia 65\%, Lymphopenia 55\% and Thrombocytopenia 35\%. The commonest peripheral smear picture was Normocytic Normochromic anemia 46\% followed by Microcytic Hypochromic Anemia 24\%
\end{abstract}

Keywords: Tuberculosis, Pulmonary Tuberculosis, Anemia, ESR, Thrombocytopenia

\section{Introduction}

Tuberculosis remains in the first place in causing morbidity and mortality among the people worldwide. It affects people medically, socially and economically.In 1991 WHO recognized TB as a major health problem among the persons and named it as "Global Emergency" and targeted the detection of 70\% new sputum smear positive and curing around $85 \%$ cases by the year 2000. The major factors for the spread of tubercle bacilli are poverty, migration and immunosupressed conditions. This makes the available drugs to become resistant and resulted in $1 / 3$ rd of patients becoming multi drug resistant. $10 \%$ of people developed into active disease and makes treatment to become difficult and leads to emergence of Extreme drug resistance. Emergence of MDR-TB and XDR-TB occur most frequently in low income countries like Africa and India. Tuberculosis remains as a major communicable disease worldwide, especially in India and nearly $1 / 3$ of population in India are affected with TB and about half of the population are in contact with pulmonary TB patients. India tops the list of Tuberculosis worldwide and accounts for about $1 / 5^{\text {th }}$ of the cases. In India ,TB most commonly affects the age group of 15-60 years and leads to increasing the burden of treatment and mortality. Hematological manifestations are more common in TB patients and deaths are also noted due to co morbid conditions like Anemia with cardiac failure, Pancytopenia, etc., In order to know about the hematological manifestations in tuberculosis, this study is conducted among 100 patients in Government Thiruvannamalai medical college and hospital from June 2014 to April 2015 .

\section{Aims And Objectives}

The study is done to evaluate the presence, extent and severity of hematological manifestations in Pulmonary and Extra pulmonary Tuberculosis.

\section{Source Of Data:}

\section{Materials And Methods}

The study was conducted among 100 patients in Government Thiruvannamalai medical college and hospital from June 2014 to April 2015. All cases were selected based on inclusion and exclusion criteria. A detailed history was elicited, clinical examination and all required investigations were done for all cases.

\section{Inclusion Criteria:}

Patients with all forms of Tuberculosis(Newly detected) 


\section{Exclusion Criteria:}

1. Tuberculosis with HIV disease

2. Tuberculosis with Renal disease

3. Tuberculosis with Liver disease

4. Tuberculosis with Hematological diseases.

5. Tuberculosis with Bleeding disorders.

Statistical Analysis:

\section{Statistical Methods}

The data was analysed with the help of softwares such as SPSS 14, MICROSOFT EXCEL 2013, MEDCALC AND GENSTAT version 9.0

Case Definitions:

Pulmonary Tb: Involvement of lung parenchyma by the tubercle bacilli as evidenced by clinical signs and symptoms, Sputum AFB and radiological studies that proved the diagnosis of tuberculosis.

Tb Meningitis: Involvement of meninges by tubercle bacilli and evidenced by CSF analysis.

Disseminated Tb: Involvement of 2 or more non contiguous organs by tuberculosis.

Miliary Tb: Acute diffuse dissemination of Tuberculosis from the primary site of infection with formation of small $<2 \mathrm{~mm}$ discrete foci of granulomatous tissue.

Relapse: Previously diagnosed as sputum positive pulmonary TB and treated and declared cured and presenting again as sputum positive case.

Failure: A patient who was initially smear-positive and who remained smear positive a month of 5 or later during treatment.

Default: A patient whose treatment was interrupted for 2 consecutive months or more.

\section{Age, Sex And Socio Economic Status:}

\section{Discussion}

The study conducted in Thiruvannamalai medical college and hospital from June 2014 to April 2015 with 100 patients of which 78 were males and 22 were females. Bozosky $\mathrm{G}^{2}$ et al studied about 380 cases of Tuberculosis. K.J. Singh ${ }^{3}$ et al studied about 55 cases of tuberculosis. The article published by Raina $\mathrm{S}^{4}$ et al contained 40 pulmonary Tuberculosis cases. Oliva V.M. ${ }^{5}$ et al also studied about 80 Pulmonary Tuberculosis cases. Uma devi ${ }^{6}$ et al studied about 117 cases of tuberculosis. Sei Won Lee ${ }^{7}$ et al studied nearly 880 cases of tuberculosis in their country. Al-Omer ${ }^{8}$ et al studied 50 cases in which 30 were males and 20 were females. R D Baynes $^{9}$ et al released the article Reactive Thrombocytosis in Pulmonary tuberculosis of clinical Pathology in 1987 and had studied about 122 cases. K.N.P. Sinha ${ }^{10}$, S. Krishnamoorthi and J.C. Chatterji in their article Disseminated Tuberculosis and Abnormal Haemopoietic Responses published in Indian journal 1977 studied about 20 cases. Abdel Salam EL Shamy ${ }^{11}$ et al studied about 34 cases of miliary TB.

Symptoms At Presentation

\begin{tabular}{|l|l|l|l|l|l|}
\hline SYMPTOMS & $\begin{array}{l}\text { PRESENT } \\
\text { STUDY }\end{array}$ & $\begin{array}{l}\text { S.F. } \\
\text { Hussain } \\
\text { et al }\end{array}$ & $\begin{array}{l}\text { Abdel Salam } \\
\text { EL Shamy } \\
\text { et al }\end{array}$ & $\begin{array}{l}\text { Mehrdad } \\
\text { Hasibi et al }\end{array}$ & $\begin{array}{l}\text { Sei Won } \\
\text { Lee et al }\end{array}$ \\
\hline TYPE & ALL TB & MIL TB & MIL TB & DIS TB & ALL TB \\
\hline FEVER & $100 \%$ & $81 \%$ & $91 \%$ & $100 \%$ & $100 \%$ \\
\hline NIGHT SWEATS & $57 \%$ & $7 \%$ & $61 \%$ & $72 \%$ & \\
\hline HEMOPTYSIS & $25 \%$ & $2 \%$ & $17 \%$ & & \\
\hline COUGH & $100 \%$ & $41 \%$ & $82 \%$ & $71 \%$ & $74 \%$ \\
\hline $\begin{array}{l}\text { BREATHLESSNES } \\
\text { S }\end{array}$ & $48 \%$ & $25 \%$ & & $38 \%$ & $65 \%$ \\
\hline $\begin{array}{l}\text { LYMPHADENOPA } \\
\text { THY }\end{array}$ & $6 \%$ & $18 \%$ & $35 \%$ & $16 \%$ & $7.6 \%$ \\
\hline CNS & $18 \%$ & $9 \%$ & & $4 \%$ & $11 \%$ \\
\hline LOSS OF & $88 \%$ & $49 \%$ & $75 \%$ & $100 \%$ & \\
\hline
\end{tabular}




\begin{tabular}{|l|l|l|l|l|l|}
\hline APPETITE & & & & & \\
\hline LOSS OF WEIGHT & $62 \%$ & $49 \%$ & $88 \%$ & $100 \%$ & \\
\hline
\end{tabular}

From the present study, we came to know that fever is the most common symptom in almost all patients. In $84 \%$ of our patients fever presented more than 2 weeks. Cough with expectoration, loss of weight and loss of appetite were other common manifestations apart from fever.

\begin{tabular}{|l|l|l|} 
Smoking, Alcohol And Tuberculosis \\
\begin{tabular}{|l|l|l|}
\hline & Olivia V.M.et al & Present study \\
\hline TYPE & Pulmonary TB & All TB \\
\hline SMOKING & $73.75 \%$ & $38 \%$ \\
\hline ALCOHOL & $43 \%$ & $32 \%$ \\
\hline
\end{tabular}
\end{tabular}

In our study we found that $38 \%$ of patients were smokers and $32 \%$ of patients were alcoholics.

\section{Types Of Tuberculosis}

The different types of tuberculosis in our study were: Pulmonary TB of $63 \%$,TB meningitis $16 \%, 4 \%$ of patients with miliary TB, disseminated TB with $11 \%$ and $4 \%$ with Pleural effusion and $1 \%$ each with TB lymphadenopathy and pericardial effusion.

\begin{tabular}{|l|l|l|l|}
\multicolumn{2}{l}{ Haematological Indices In Tuberculosis } \\
\hline & I A Al Omar et al & Seyed Mehdi Mirsaeidi et al & Present Study \\
\hline PARAMETERS & ALL TB & PULMONARY TB & ALL TB \\
\hline MEAN \pm SD & & & \\
\hline Hb & $12.68 \pm 2.25$ & $13.16 \pm 2.41$ & $9.3 \pm 2.49$ \\
\hline RBC & $4.61 \pm 0.74$ & & $3.94 \pm 1.12$ \\
\hline PCV & $37.44 \pm 6.86$ & $40.48 \pm 7.67$ & $30.32 \pm 8.58$ \\
\hline ESR & $76.13 \pm 34.89$ & $53.8 \pm 34$ & $52.82 \pm 34.46$ \\
\hline MCV & $83.28 \pm 7.28$ & & $79.0 \pm 13.8$ \\
\hline MCH & $28.07 \pm 2.76$ & & $26.02 \pm 6.6$ \\
\hline MCHC & $32.86 \pm 0.75$ & & $31.59 \pm 4.10$ \\
\hline
\end{tabular}

In our study we found that Hemoglobin\% was 9.3 \pm 2.49 when compared to I A Omar et al 12.68 2.25 . By this we came to know that the present study showed prevalence of anemia in all TB cases. Other parameters were similar in all studies.

\begin{tabular}{|l|l|l|l|}
\multicolumn{5}{|c|}{ Bmi And Esr } \\
\hline & PRESENT STUDY & K J Singh et al & Uma Devi et al \\
\hline PARAMETERS & Mean \pm SD & & \\
\hline BMI & $17 \pm 3.18$ & $17.6 \pm 0.52$ & $17 \pm 0.25$ \\
\hline ESR & $52.82 \pm 34.46$ & $56.62 \pm 35.57$ & $86 \pm 130$ \\
\hline
\end{tabular}

In the present study BMI was $17 \pm 3.18$ which was similar to K J Singh et al and Uma Devi et al. But , recording the Mean ESR, it is elevated in the Uma Devi et al $(86 \pm 130)$ study when compared to the present study $(52.82 \pm 34.6)$.

\section{Prevalence Of Anemia In Tuberculosis:}

Sei Won Lee et al in their study found that 281 cases of anemia. 45 cases had $<10$ gm\% and 13 cases had $<7 \mathrm{gm} \%$ and the most common feature was Normocytic Normochromic Anemia. K N P Sinha et al showed in their study that 20 cases of disseminated TB were anemic and again the most common feature was Normocytic Normochromic Anemia followed by Microcytic Hypochromic Anemia. S F Hussain et al found that $62 \%$ were anemic in his study out $2 \mathrm{f} 112$ cases of miliary TB. Ali et al showed the prevalence of anemia in $76 \%$ of cases. Mehrdad Hasibi et al in their study on disseminated TB showed that $65 \%$ of their patients were anemic. Maarteends $\mathrm{G}$ et al found the prevalence of anemia to be about $74 \%$ in their study on Miliary TB. Al Jahadali et al found the anemia prevalence was $66 \%$ in their study. Abdel Salam EL Shamy et al studied about 34 cases of Disseminated TB and found that $65 \%$ of cases were anemic. Raina $\mathrm{S}$ et al showed the anemic prevalence about $92.5 \%$ in their study. K J Singh et al in their study found that 47 cases were anemic and 11 were severely anemic. K N P Sinha et al in their study found that all patients to be anemic.

In our study out of 100 patients studied 48 patients had moderate anemia and 17 had severe anemia out of which 46 were Normocytic Normochromic Anemia; 24 were Microcytic Hypochromic Anemia; 17 were Dimorphic Anemia; 10 were Normocytic Hypochromic Anemia and 3 were Microcytic Hypochromic Anemia 
Wbc Indices

\begin{tabular}{|l|l|l|l|l|l|l|l|}
\hline PARAMETERS & Raina S et al & $\begin{array}{l}\text { KNP Sinha et } \\
\text { al }\end{array}$ & $\begin{array}{l}\text { F Hussain et } \\
\text { al }\end{array}$ & \multicolumn{2}{l|}{ KJ Singh et al } & \multicolumn{2}{l|}{ Present Study } \\
\hline TYPE & PTB & $\begin{array}{l}\text { DTB/ } \\
\text { MTB }\end{array}$ & MTB & PTB & $\begin{array}{l}\text { DTB/ } \\
\text { MTB }\end{array}$ & $\begin{array}{l}\text { PTB } \\
\text { DTB/ } \\
\text { MTB }\end{array}$ \\
\hline LEUCOPENIA & 0 & $45 \%$ & $6 \%$ & 0 & $25 \%$ & $16 \%$ & $27 \%$ \\
\hline NEUTROPENIA & 0 & $20 \%$ & $6 \%$ & 0 & $22 \%$ & 0 & $9 \%$ \\
\hline LYMPHOCYTOPENIA & $5 \%$ & & $71 \%$ & $21 \%$ & $34 \%$ & $62 \%$ & $27 \%$ \\
\hline $\begin{array}{l}\text { THROMBOCYTOPENI } \\
\text { A }\end{array}$ & 0 & $30 \%$ & $26 \%$ & $4 \%$ & $34 \%$ & $32.7 \%$ & $72 \%$ \\
\hline LEUKOCYTOSIS & $5 \%$ & $15 \%$ & $37 \%$ & $26 \%$ & $12.5 \%$ & $24 \%$ & $77 \%$ \\
\hline NEUTROPHILIA & $10 \%$ & & $30 \%$ & $26 \%$ & $12.5 \%$ & $81 \%$ & $27 \%$ \\
\hline THROMBOCYTOSIS & 0 & 0 & $8 \%$ & & & $16 \%$ & \\
\hline
\end{tabular}

Neutropenia, Leucopenia and Lymphocytopenia in Miliary TB and Disseminated TB was comparable with other studies Hussain et al, K N P Sinha and K J Singh et al. Thrombocytopenia was significantly increased in our study when compared to other studies in both miliary and disseminated TB.

\section{Summary}

- The study contained 100 cases of newly detected Tuberculosis patients out of which 78 were males and 22 were females. Maximum number of cases were in fifth to sixth decade(46-55) of life

- The commonest symptoms that we found were Fever, Cough with Expectoration, Hemoptysis, Dyspnoea, Loss of weight and Loss of appetite.

- The commonest type of Tuberculosis is Pulmonary form of about $63 \%$ followed by Extra Pulmonary TB $16 \% ; 11 \%$ had Disseminated TB ; 4\% had pleural effusion; 4\% had Miliary TB; $1 \%$ TB lymphadenopathy and $1 \%$ Pericardial effusion.

- The commonest hematological findings were raised ESR $84 \%$, followed by anemia $65 \%$, Lymphopenia 55\% and Thrombocytopenia 35\%.

- The commonest peripheral smear picture was Normocytic Normochromic anemia $46 \%$ followed by Microcytic Hypochromic Anemia 24\%

- Severe abnormalities were found in both Miliary and Disseminated TB (15\%). This increases the overall mortality and morbidity in tuberculosis patients.

\section{Conclusion}

- In our study, anemia was the most commonest hematological abnormality in all forms of tuberculosis

- The degree of anemia is directly proportional to the severity of tuberculosis and severe anemia in turn increases the morbidity and the mortality in tuberculosis. Thus in India poverty, poor nutritional status, overcrowding and immunocompromised states leads an increase in the \% of anemia in TB is noted.

- The commonest finding in our study is moderate anemia with normocytic normochromic picture in the peripheral smear study followed by microcytic hypochromic anemia.

- Increased ESR is the commonest finding associated with tuberculosis.

- Presence of other hematological manifestations like leucopenia, lymphopenia and thrombocytopenia in all forms of TB further increases morbidity and mortality.

\section{References}

[1]. SK Sharma. Introduction,Tuberculosis,2 nd ed,Jaypee publications 2009;1.

[2]. Bozoky G, Ruby E, Goher I, Toth J, Mohos A Hematologic abnormalities in Pulmonary Tuberculosis published in the journal Orv Hetil. 1997 Apr 27;138(17):1053-6

[3]. K J Singh et al Significance of Hematological manifestations in patients with Tuberculosis Journal of Academy of Physicians of India Aug.2001.

[4]. Raina S et al Hematological changes in Pulmonary Tuberculosis published in the journal The Indian Practitioner,Feb.2010.

[5]. Oliva V.M., Cezario G.A.G., Cocato R.A., Marcondes-machado J. Pulmonary Tuberculosis: Hematology,Serum Biochemistry and the relation with the disease duration published in Journal of Animal Toxins including Tropical diseases March 2008.

[6]. Uma Devi et al Effect of iron supplementation on mild to moderate anemia in Pulmonary Tuberculosis Published in Journal of nutrition 2003.

[7]. Sei Won Lee et al the prevalence and evolution of Anemia associated with Tuberculosis published in the Journal of Korean Med Sciences 2006;21:1028-32.

[8]. Al-Omer et al Hematological abnormalities in Saudis suffering from Pulmonary Tuberculosis and their response to treatment published in Research Journal of Pharmacology 2009.

[9]. R D Baynes et al Reactive Thrombocytosis in Pulmonary Tuberculosis published in Journal of clinical Pathology 1987.

[10]. K.N.P. Sinha, S. Krishnamurti and JC Chatterji Ind.J.tub., vol. xxiv no. 3,1977 Disseminated Tuberculosis and Abnormal Haemopoietic responses.

[11]. Abdel Salam El Shamy, Fatma Al Saidi, Ghassan Baidas, Mohammed Al Bader, Mohammed Sawy, Rismon Hakk Miliary Tuberculosis in Kuwait: Clinical Presentation,Diagnosis and Treatment outcome December 2008. 